\title{
The Role of Leadership in the Organization and the Administration of Women's Agricultural Cooperatives in Greece: A Case Study
}

\author{
Lassithiotaki Aikaterini \\ Department of Rural Development, Municipality of Heraklion, Heraklion, Greece \\ Email: katlas@hol.gr
}

Received 3 November 2014; revised 2 December 2014; accepted 15 December 2014

Copyright (C) 2015 by author and Scientific Research Publishing Inc.

This work is licensed under the Creative Commons Attribution International License (CC BY). http://creativecommons.org/licenses/by/4.0/

\section{(c) () D Den Access}

\section{Abstract}

This paper investigates the role of chairwomen in the organization and administration of Women's Agricultural Cooperatives at the Prefecture of Heraklion, in the island of Crete, Greece. The aim of the research is to provide answers to the questions "how" and "why" the chairwomen affect the organization and the administration of cooperatives and it is focused on the administrative, social, cognitive, personal and entrepreneurial skills of chairwomen. The results of a qualitative study involving 12 chairwomen of rural women's Traditional Food Production Cooperatives of the Prefecture of Heraklion indicated that their role was multiple and complex and it affected positively the organizational and entrepreneurial process of the Cooperatives. On the other hand, the research indicated that the chairwomen's role did not differ significantly from the role of other members. Their role in the organization and operation of the Cooperatives is more managerial and less leadership.

\section{Keywords}

Women's Agricultural Cooperatives, Leadership, Prefecture of Heraklion, Greece

\section{Introduction}

The entrepreneurial activity of the women's agricultural cooperatives in Greece has been studied by many researchers. Women's agricultural cooperatives have contributed to the financial sector of mountainous or less favored areas, to the family rural income and to the self confidence of rural women. Besides their positive con- 
tribution, studies have shown that the elderly population along with the low level of education and training possessed by the members of the women's agricultural cooperatives inhibited the application of innovative ideas in the entrepreneurial activities undertaken by the cooperatives [1]-[3].

The members of the Administrative Councils of the women's agricultural cooperatives are members of the cooperatives themselves, they are elected by the General Assembly and form the leadership of the cooperatives. The term "leadership" refers to the influence that an individual or a group has on other individuals or groups with the aim of manipulation for the achievement of their goal [4], while the ability of a leader is the ability to guide people in order to create things that they don't consider they are able to create or they do not realize that these things should become real [5]. The leadership of an organization or a company sets goals, plans their fulfillment, motivates the members of the group to pursuit these goals [6] and plays an important role in the orderly operation of the organization and the development of an entrepreneurial culture on the part of its members. The motives, the personality, the behavior, the potentials and the skills of the leaders affect the organizational operation and the success of an organization.

Taking all of the above into consideration, this case study investigated the role of the chairwomen of the women's agricultural cooperatives of the Prefecture of Heraklion in Crete in the organization, the administration and the entrepreneurial progress of the cooperative.

\section{Rural Women and Leadership Skills in Rural Women Cooperatives}

The abilities that are essential for the leadership of an organization or a company and contribute to the successful administration of an organization or a company are the cognitive ability, the communicational ability and the specialization [7] [8].

Researchers claim that women lack in the way they administrate because they set low goals, they lack self confidence and do not take risks (they are more moderate) due to the fear of failure or criticism [9] [10]. Other researches, however, that have focused primarily on the personal behaviors of men and women as far as the administrative method is concerned, prove that there are no important differences in the behaviors between gender [11]-[16]. The differences found between male and female executives refer to the type of leadership that the two sexes prefer. Women seem to encourage participation more than their male colleagues, they share the power and the information and they try to increase the self-confidence of the members of the group, while men prefer to base themselves on their knowledge, to support themselves by the status of their position and influence the members of the group [4]. Singh and Vinnicombe [10] share the same view stating that women detect the individual efforts of the members of the group, share the praise, believe in the fairness of the official structures of the organization and are better in team work and communication.

Rural women of Greece, members of women's agricultural cooperatives are lacking of formal education and training in the agricultural sector, as well as on the use of new technologies and the Internet [1]. Other studies conducted in Greece have underlined the lack of organizational and administrative experience on the part of the members. The lack of administrative and organizational experience by the Administrative Councils of the women's agricultural cooperatives and their chairwomen often results in problems in the division of the work load and conflicts among the members of the cooperatives [1]-[3] [17].

The leadership of women's agricultural cooperatives plays an important role in the operation of the cooperatives and in the avoidance of conflicts as the behavior of the leadership is crucial for the orderly operation of an organization [18]. The dissatisfaction of the members from the operation of the administration leads to the alienation of the cooperatives members and increase the possibilities of the cooperatives to be abandoned by the members [19]. The flexible hours (flexibility in working hours and in payment), the quality, the dedication of the employees to the company and the continuous training enhance the operation of the companies [20].

The European Commission has set as an important priority for the development of entrepreneurial culture, which includes administrative, social, personal and entrepreneurial skills. These skills include the ability to solve problems, planning, decision making, communication, undertaking responsibilities, collaboration, networking, undertaking new roles, critical and independent thinking, desire for autonomous learning and confrontation of dangers concerning the materialization of ideas [21]-[28].

\section{Heraklion Prefecture Geographic Area}

The Heraklion Prefecture, on the island of Crete, Greece, makes up more than 50 percent of the population of 
the whole island, produces the largest per capita Gross Domestic Product, provides most of the rural production and hosts more than 50 percent of the industrial enterprises.

Nonetheless, the agricultural sector of the Heraklion Prefecture faces the same problems as every other rural region in Greece. The division of farmlands into small lots located at great distances from one another, the limited natural resources, the aging of the rural population and the low education level are few of the problems [29].

Additional economic constraints in the Prefecture Rural Sector are high production and transport costs, poor agricultural cultivation methods, high dependency on agriculture subsidies, limited processing and packaging of farm products, weak cooperative organizations and rural enterprises that do not promote their products as having high added value. Most enterprises have limited possibilities for innovative actions-such as the use and assimilation of new technologies because they are active only at a local level using a familial cooperative style [29].

\section{Rural Women's Agricultural Cooperatives}

In Greece, mainly from the mid 1980's onwards, rural women participated in women's cooperatives. The continuously increasing number of Cooperatives resulted from the promotion of cooperative entrepreneurship by the public policies. The participation of rural women in cooperatives was mainly reflected in a change in woman's status within the society [2].

Women's agricultural cooperatives are businesses in traditional sectors of female employment in the tertiary sector (commerce, services) and addressed to end consumers. Most of them produce and sell traditional food products made with raw materials from their regions of activity (oil, wine, milk, eggs). A smaller number of cooperatives are active in the agro-tourism sector, as well as in the home handicrafts' sector, producing folk art items such as embroideries and traditional costumes [1].

Up to now, accurate data on the number of female agricultural cooperatives do not exist. In 2012, the Greek Ministry of Rural Development and Food created the National Register of rural cooperatives, in which all national cooperative organizations in the country should be entered. The registration of cooperatives in the Register is not finished yet and therefore the exact number of female agricultural cooperatives in Greece is not known accurately. However, an informal list of the Ministry of Rural Development and Food shows that the total number of women's agricultural cooperatives in Greece is 140 and 12 of them are currently operating in the Heraklion Prefecture. All of 12 women's agricultural cooperatives are located in settlements with less than 2000 residents and in mountainous or less favored areas of the Heraklion Prefecture and all of them produce and sell traditional food products made with raw materials from their regions of activity (oil, wine, milk, eggs). The establishment of less favored areas was implemented with Directive 75/268 [30], as a support program for farmers and cattlemen in areas where rural production is bounded by restrictions of geographical (mountainous, semimountainous, barren), political, social and economic constraints (such as areas with demographic shrinkage, isolated locations, areas in borders). The creation of a national and European support program is necessary for their further development [31] [32].

\section{Sample and Method}

Considering that the objective of the research was to describe, comprehend and analyze the social processes, answering the questions "how" and "why," the chairwomen affect the organization and administration of the cooperatives, the qualitative methodology of a case study was particularly useful [33]. The survey ran from March to July 2014. The main stage of the research was based on empirical data. The data collection was obtained through individual semi-structured interviews [34]. The questionnaire was focused on the administrative, social, cognitive, personal and entrepreneurial skills of chairwomen and the questions of semi-structured interviews were about:

- The connection of the cognitive, social and individual skills of the chairwomen to the taking up of a leading role in the cooperative (e.g. educational level, former work and administrative experience, personal skills).

- The connection of the administrative and entrepreneurial skills of the chairwomen with the operation and the administration of women's agricultural cooperatives (e.g. the ability to solve work conflicts, the assumption of administrative and entrepreneurial responsibilities and initiatives).

Because this research is a case study that followed the qualitative research approach, the data is context-specific. This implies that there cannot be a generalization of results. This research can give some useful prompts 
for further study of its results in other regions of Greece, as well as provide some insights on how the chairwomen's skills affect the administration and the organization of the cooperatives.

The qualitative method approach often elicits criticism about the lack of subjectivity, the difficulty of reproducing it and the lack of transparency [35]. To offset these disadvantages, processes and methods were used that ensured, as much as possible, the applicability, objectiveness, reliability and the validity of the research. During the research, a diary on every step and action taken was regularly updated [36]-[38]. Before beginning the research process, the cooperatives were informed orally and in writing about the aim of the research and how the anonymity of each chairwoman would be guaranteed [39]. Also, they were given instructions about the interviews with real and not merely agreeable information. At first, a trial interview was conducted with a chairwoman in order to conclude that the user friendliness of the semi-structured questionnaire was acceptable [37]. During the interviews, the experiences and perspectives of the interviewee were recorded without personal opinions or any biases on behalf of the researcher being involved [40] [41]. In addition, the chairwomen verified the transcripts concerning their answers [39].

Each interview lasted for 40 - 50 minutes and took place in the offices of the cooperative's Chairwoman, without the presence of other members. Following the transcription of the interview recordings, a pen name was given to each interview to ensure the anonymity of the chairwomen. A second meeting/interview that lasted for 10 minutes was arranged with each chairwoman to clarify initial answers and to ask follow-up questions. After the second transcription of the recordings, there was telephone contact with some of the chairwomen (3 - 5 minute duration) to clarify certain vague points. With this procedure, the questions and answers of the original interview were enriched.

Content analysis of the interviews was applied to draw results from the qualitative interviews [42]-[44]. The texts from the answers were used as the initial data base. They were then divided into smaller sections and analysis units were created. These units were parts of the texts that contained a piece of information that was comprehensible even outside the context. This information was then classified in axes, starting from the specific to the general [45].

\section{Results}

\subsection{The Cognitive, Social and Personal Skills of the Chairwomen and the Administration of the Cooperatives}

\subsubsection{The Cognitive Skills and the Administration of the Cooperatives}

The higher educational level in comparison to the other members is considered a prerequisite for the communication with the representatives of support institutions and the realization of financial and bureaucratic administrative procedures. The chairwomen are the ones who represent the cooperatives in all the procedures and the events related to the cooperative. Needless to say that 6 out of the 12 chairwomen are Senior High School graduates and 2 of them are high school graduates: a fact that does not comply with the average educational level of the members.

Apart from the educational level, former work and administrative experience is considered as an additional ability that contributes to the successful administration of the cooperative. Former work experience or/and a previous administrative experience in other association helped in the acquisition of administrative and financial knowledge that are valuable for the foundation and administration of the cooperative, for the communication with the representatives of various institutions and for the realization of financial and bureaucratic procedures.

Here are some indicative answers to the issues mentioned:

"I had some additional skills and knowledge in comparison to the other girls, I used to work in hotels, I had graduated from Senior High School and Intensive School of Touristic Professions at the Manpower Employment Organization of Greece...I believed I could run more than the others to the public services." (Marianthi)

"I have graduated from Senior High School. I surely understand more than the others when it comes both to public services and schedules. I could move more easily.” (Sofia)

"In a way we have distributed the responsibilities among the members of the Council. A girl used to be a treasurer in the cultural association and she became treasurer in the cooperative as well. I had graduated from Senior High School, I could run to public services.” (Dora) 
"I had work experience, I knew how to set up a company, to run to public services, to talk to the people responsible for the bureaucratic procedures. So I ran for the cooperative a lot and I was successful. That is why I was elected chairwoman.” (Chrisoula)

"I had conceived the meaning of the cooperative and its problems. I knew what we had to do. I knew that we should find new markets and at the same time we ought to reduce the cost. I knew that we should use fine ingredients and people trust us. I was a treasurer in the former administration and thus I had understood the idea of the cooperative from an administrative aspect. It is not particularly difficult for me to be a chairwoman.” (Vaso)

The interviews indicated that the low educational level of the rural women that participate in the women's agricultural cooperatives of the Prefecture of Heraklion and the lack of administrative and work experience influences the ability to carry out the bureaucratic procedures that are necessary for the foundation and for the financial and administrative operation of cooperatives. Thus, the cognitive skills are crucial parameters for the undertaking of leadership.

\subsubsection{The Car Driver Ability and the Administration of Cooperatives}

It is interesting how the car driving ability turned out to be an essential skill as a leader. In the mountainous and less favored areas of Heraklion Prefecture the car driver ability plays a crucial role in the orderly operation of the cooperative. In most cases the chairwomen were the only ones who could drive in the beginning of the operation of cooperatives and they could go to the city of Heraklion for financial issues (e.g. loans, funds), to receive updates from the various institutions, to receive orders from stores and clients, and for the distribution of the products of the cooperative. The rural women who could drive were more dynamic than the others since they were independent from their husbands on this issue. They could travel to the city of Heraklion and they were more sociable than the other members. During the operation of cooperatives, other members have acquired the ability to drive: a fact that proves the contribution of entrepreneurship in the independence of rural women. However, there are some cooperatives where the chairwoman continues to be the only person with the driving ability and this inhibits the entrepreneurial progress of the cooperatives. In these cases, the chairwoman does not have enough time to deal with the order of raw material for the cooperative, the distribution, the communication with the representatives of various institutions and the administrational operation of the cooperative.

Here are some indicative responses:

“I knew how to drive while the others didn’t. Thus I could do more things for the cooperative ... unfortunately I am the only one who drives and I cannot find time for everything. We often reject invitations from Heraklion because I cannot go.” (Sofia)

"I was the only one who could drive at that time, now two more women have taken the driver's license, and I could run more that the others since I had a car." (Irene)

"Me and another girl drove at the time. Thus, I could go to public services." (Gianna)

"Besides knowing some things more than the other girls, I was the only one who could drive at the time.

Now many women can drive.” (Marianthi)

\subsubsection{The Communication Skills and the Administration of Cooperatives}

The communicative ability is considered as an advantage for the position of the chairwoman in the women's agricultural cooperatives of the Prefecture of Heraklion and it helps in the contact with the representatives of the various institutions. Rural women, due to their low educational level, find it hard to express their various requests to the institutions and close deals with big stores. The communicative ability is recognized as a gift by them, even if it does not go along with other skills.

Here are some indicative answers:

"I consider myself to be suitable for president. I can do the talking; I can communicate with other people more easily. When it comes to closing a deal in Heraklion I go there myself and I talk the nice way....." (Gianna)

"We talked about any issue in the beginning and then we assigned any task to the former chairwoman, who had been in this place for 6 years, because she was more spontaneous; she could talk even though she hadn't graduated from high school like I had. She was present to all the invitations that we received by the 
supporting institutions and she understood what we had to do.” (Niki)

\subsection{The Administrative and Enterprising Skills of Chairwomen and the Administration of Cooperatives}

\subsubsection{The Role of the Chairwomen in the Conflicts among the Members}

Analysis showed that only in extreme organizational and administrative crises, when the cooperative faces the risk of falling apart, chairwomen and members take up initiatives and the responsibility to deal with the crisis, so that the cooperative can continue to operate.

"The former chairwoman wanted to control everything. She did not inform us about the things she was doing; she wanted to take all decisions on her own... At the beginning of the operation of the cooperative, the fact that she dealt with everything on her own was convenient for us because we had no responsibility. But the situation got to extremes due to her behavior. The expenses of the cooperative were increased due to her management without providing any information to the members. Because of the debts created the cooperative went nearly bankrupt. The cooperative belongs to its members so we reacted. Someone else had to be in charge. Being the treasurer in the previous administration, I had the time to be actively involved in the cooperative and because my belief was that things had be changed and we should stop being passive, I became chairwoman. Nowadays members are more mature, they know what they want and they do not tolerate any oppression...” (Vaso)

"In the beginning some women had joined the cooperative but they kept causing troubles. They did not work and they grumbled about the work hours. They did not like the goals set by the cooperative and they did not help the rest members to organize the cooperative. We had conflicts all the time with these women. We had almost fallen apart and the cooperative did not operate at all. We talked about this issue with the other members, we called a General Assembly and we set there all the issues. We agreed on my becoming a chairwoman. Now we go along just fine, things are going like clockwork.” (Sofia)

"A rural woman that became member of the cooperative within the last year has created many problems. Her husband opened up a workshop and produced the same products we did. He began to compete with us for the clients. He even stole our recipes. Our statute clearly is stated that a relative or a husband of any of the cooperative members was not allowed to establish a business which will produce similar products with the products of the cooperative. We called up a General Assembly, we voted and we expelled her from the cooperative. Now we are more united and we try to sell more of our products." (Daphne)

In the personal conflicts among the members (e.g. different opinions) the chairwomen do not resume responsibility for the resolution of conflicts at once. As they characteristically mention they prefer to "let it go".

"The disagreements are solved after some time through conversation. There are also some issues that we cannot solve through conversation. Usually these are sensitive, personal cases. I let them go. We do not deal with them so that any further conflicts are avoided.” (Niki)

When the conflicts among the members are not very tense, the problems that arise are discussed in a face to face conversation in the presence of the chairwoman, who undertakes the role of the negotiator and/or mediator.

"When we have personal conflicts we talk about them face to face... This is the best reaction." (Marianthi)

"If there are personal conflicts—'You did this, you did that'—we deal with it through discussion." (Dimitra)

"If there are any personal issues we usually talk about them. I always try to ease the situation.” (Chrysoula)

The rest of the issues like the assignment of duties and shifts are dealt on the basis of the internal regulations of the cooperatives. All the cooperatives have internal regulations which determine the duties and working hours. In all cooperatives the members work two shifts and in 9 out of 12 cooperatives there is no specialization of duties. In the other 3 there is specialization in the productive process and in the organizational departments of the cooperative. The main daily problem in the operation of the cooperatives seems to be the request of the members for a change in their predetermined shift in the cooperative. The request is dealt with discussion and all possible attempts are made in order to avoid conflict.

Here are some indicative answers about the administrative organization of the cooperatives and the ways of resolving any personal conflicts among the members: 
"We all do all the chores.” (Sofia, Irene, Gianna, Niki, Dimitra, Chrysoula, Dora)

"Based on the different products we produce we form groups. Each group produces a different product." (Marianthi)

"Most women have a specialization; others in sweets, others in cookies, etc. Moreover, there is also a specialization in specific positions... If a member has a problem and she cannot work, we talk about it and we find which member will substitute her.” (Vaso)

"For example 4 members may happen to need to alternate shifts at the same time and this is something that cannot be done. Then we talk about it and we come up with a solution. One may retreat, another may change her shift, we just talk about it and we solve it.” (Dora)

\subsubsection{The Role of the Chairwomen in Relation to the Entrepreneurial Initiatives of the Cooperative}

The chairwomen do not seem to take up more responsibilities and initiatives in comparison to the other members on issues that refer to the purchase of raw material and the promotion on issues like the advertising of the cooperative. Most of the time, the only initiative of chairwomen is to close a deal or to buy a small amount of raw materials, initiatives that are also undertaken by the other members. Particularly on issues of entrepreneurship, even if it is about the advertising of the cooperative and for a small cost that has to be paid for an exhibition, the chairwomen do not resume any responsibility or initiative. In one case only the members has authorized the chairwoman to decide on her own about such issues.

The reason that the chairwomen mentioned their refusal to resume even the slightest responsibility or initiative on issues of entrepreneurial procedures is the democratic type of their leadership.

Thus, the chairwomen of the cooperatives, apart from the matters that call for a General Assembly according to the statute of the cooperative, or/and are included in the general entrepreneurial goal and progress (e.g which new products should be produced and through which productive procedures, asking for a loan, etc), they decide along with the other members about all of the other minor issues that refer to simple entrepreneurial procedures. All of the decisions are taken either in typical General Assemblies or in informal meetings among members.

Here are some indicative responses from the chairwomen:

"I don't want to take all the decisions by myself. I want to share the responsibility and also I do not like the other members to think that I do whatever I want.... We all take orders for products without asking the chairwoman. If one of us knows what a raw material is needed, she will buy it, without asking. A small amount of course. We are only 7 people and we meet every day. In this sense we have a General Assembly every day because we talk about everything." (Dora)

"I am very democratic...We take decisions about serious issues all together. Once, there was a problem with one of our products, cottage cheese. Some clients wanted it to be produced in a special way some others in a different way. We had to decide what to do. We took this decision in a General Assembly. This is how I share the burden of responsibility and I never want to be bossy in my decisions.... I take some minor decisions on my own. Today, for example, I had a call from a radio station that asked us to become sponsors in one of the shows and I agreed without calling a General Assembly. There is a General Assembly once a month so that all the critical issues of the cooperative can be discussed.” (Vaso)

"No, the chairwoman doesn't take any decision on her own. We discuss everything all together." (Niki)

"E.g., if we want to advertise the cooperative and we will ask for offers. We will talk about the offer we are going to choose. There are many views on whether we are going to choose the cheapest offer or if other criteria are more crucial. Only if we accept an offer, I can decide on my own, but this can also be done by any member of the cooperative....All the other decisions are taken unanimously.” (Irene)

"I only take orders for products. But so do all the other members." (Chrysoula)

"Anyone of us can decide about the orders of products. Any member who is here can take an order. Each one of us can buy the raw material what we need. We don't decide on these issues in common." (Dimitra)

"I don't take any decisions nor does any other member of the cooperative. For example, a member is responsible for the orders and for checking the raw materials we need. If she is absent, someone else will take over. But we talk about this issue all together in informal General Assemblies that are called up very often, more than once a month. During the change of the shift we all gather together and we talk. We say what we are going to do, we discuss and we decide either unanimously or through majority voting. We always try to be all the members present in these meetings." (Gianna) 
"If I go to Heraklion and I believe that we need a raw material that doesn't cost a lot, I will even pay with my own money to buy it. The purchase of a great quantity of raw materials is decided in the General Assembly...... or if we want to close a deal, we will not talk about it, I will do it myself.... If we want to take part in an exhibition, we talk about it in the General Assembly.” (Sofia)

\section{Conclusions and Discussion}

The chairwomen of the women's agricultural cooperatives of the Prefecture of Heraklion had additional skills in comparison to the other members (higher level of education and/or work experience and/or administrative knowledge and/or communicational skills and and/or car driver's ability) from the very beginning of their participation in the cooperatives. They have undertaken the initiative for the foundation and the operation of the cooperatives and they have also undertaken the organizational and the administrative responsibility of the cooperatives. Some of the chairwomen have successfully dealt with the conflicts among the other members which risked the destruction of the cooperatives. Thus, they have contributed majorly in the orderly organizational and administrative operation of the cooperatives.

Their duties to the cooperative correspond to the skills they possess. They all work in the cooperatives like the other members and, at the same time, they distribute the products, they represent the cooperatives in meetings with various institutions, they inform the other members about the outcome of their meetings and the developmental goals set in relation to the mountainous and less favored areas. Moreover they administrate the necessary bureaucratic procedures and they solve daily organizational and administrative problems, like the change of shift among the members and other minor disputes and problems.

The chairwomen want to share the responsibility for any decision relevant to the enhancement of entrepreneurship in the cooperatives. They want to share the responsibility even for any decision that is not included in the statute and/or do not affect the entrepreneurial goals of the cooperatives. In almost all cases their entrepreneurial responsibility and initiative is limited to the acceptance of orders and possibly to initiative of purchasing small amounts of raw materials. However, these tasks can be carried out by all the other members. The chairwomen invoke the democratic type of their leadership and they do not undertake any responsibility or initiative for entrepreneurial activities that affect the financial status of the cooperatives, even in the slightest manner (e.g. participation to exhibitions and advertising of the cooperative).

All the aforementioned indicated that the role of chairwomen was multiple and complex and it affected positively the organizational and entrepreneurial processes of cooperatives. On the other hand, the research indicated that the chairwomen's role did not significantly differ from the role of other cooperative members in issues such as the willingness to undertake risk and entrepreneurial initiatives, the willingness to encourage innovation and change the entrepreneurial culture of cooperatives. Their role in the organization and the operation of Cooperatives is more managerial and less leadership.

A successful and effective leader has to possess insight and perception, sensitivity and communication both in the internal and the external environment of the organization and sensitivity to the needs and the problems of the members of the organization. A successful and effective leader should undertake responsibilities and initiative and encourage innovation and changes in the culture of the organization [46].

In the forum "Training in entrepreneurship", that took place at the University of Nikea, Sophia Antipolis, in October 2000, it was stated that the entrepreneurial culture included administrative, social, personal and entrepreneurial skills and was immediately connected to small and medium-sized enterprises [21] [22] [31] [32].

Some theories claim that some of the entrepreneurial dexterities can be acquired through experience or proper training [47]. The insertion of courses related to the development of an entrepreneurial culture and skills in all the levels of education and the inclusion of relevant seminars in the enterprises and the organizations will contribute to the change in the attitude of the society towards entrepreneurship and particularly the change of the attitude and the beliefs of groups of population like the members of rural women cooperatives, who have never been familiarized with the entrepreneurial spirit and the entrepreneurship [21] [22] [31].

\section{References}

[1] Lassithiotaki, A. and Roubakou, A. (2014) Rural Women Cooperatives at Greece: A Retrospective Study. Open Journal of Business and Management, 2, 127-137. http://dx.doi.org/10.4236/ojbm.2014.22016

[2] Koutsou, S., Iakovidou, O. and Gotsinas, N. (2003) Women's Cooperatives in Greece: An Ongoing Story of Battles, 
Successes and Problems. Journal of Rural Cooperation, 31, 47-57,

[3] Iakovidou, O. (1997) Agro-Tourism in Greece: The Case of Women Agro-Tourism Co-Operative in Ambelakia. Medit, 8, 44-47.

[4] Robbins, S. (1993) Organizational Behavior. Prentice Hall, Englewood Cliffs.

[5] Cohen, W.A. (1990) The Art of the Leader. Prentice Hall, Englewood Cliffs, 215.

[6] Brickley, J.A., Smith, C.W. and Zimmerman, J.L. (2001) Managerial Economics and Organizational Architecture. 2nd Edition, Irwin McGraw-Hill, London.

[7] Gibson, J.L., Donnelly Jr., J.H., Ivancevich, J.M. and Konopaske, R. (2003) Organizations: Behavior, Structure and Processes. Irwin McGraw-Hill, New York.

[8] Yukl, G. (1994) Leadership in Organizations. 3rd Edition, Prentice Hall, Englewood Cliffs, 251-280.

[9] Singh, V. and Vinnicombe, S. (2003) The 2002 Female FTSE Index and Women Directors. Women in Management Review, 18, 349-358. http://dx.doi.org/10.1108/09649420310498975

[10] Singh, V. and Vinnicombe, S. (2004) Why So Few Women Directors in Top UK Boardrooms? Evidence and Theoretical Explanations. Corporate Governance: An International Review, 12, 479-488. http://dx.doi.org/10.1111/j.1467-8683.2004.00388.x

[11] Bass, B.M. and Stogdill, R.M. (1990) Bass \& Stogdill’s Handbook of Leadership: Theory, Research and Managerial Applications. 3rd Edition, Free Press, New York.

[12] Eagly, A.H. and Johnson, B.T. (1990) Gender and Leadership Style: A Meta-Analysis. Psychological Bulletin, 108, 233-256. http://dx.doi.org/10.1037/0033-2909.108.2.233

[13] Dobbins, G.H. and Platz, S.J. (1986) Sex Differences in Leadership: How Real Are They? Academy of Management Review, 11, 118-127. http://dx.doi.org/10.5465/AMR.1986.4282639

[14] Baron, R.A. (1986) Behavior in Organizations: Understanding and Managing the Human Side of Work. 2nd Edition, Allyn and Bacon, Boston.

[15] Donnell, S.M. and Hall, J. (1980) Men and Women as Managers: A Significant Case of No Significant Difference. Organizational Dynamics Journal, 8, 60-77. http://dx.doi.org/10.1016/0090-2616(80)90049-2

[16] Maccoby, E.E. and Jacklin, C.N. (1974) The Psychology of Sex Differences. Stanford University Press, Stanford.

[17] Papageorgiou, K., Maraveyias, N., Apostolopoulos, K., Kaldis, P., Alexopoulos, G., Gardeli, C. and Yiannouzakou, A. (1999) Evaluation of Program of Agro-Tourism and Manufacturing in Rural Areas (Regular E.C. 950/97). Manuscript Published in Greek Language, Department of Agricultural Economics and Rural Development, Agricultural University of Athens, Athens.

[18] Cook, C. and Hunsaker, P.L (2001) Management and Organizational Behavior. 3rd Edition, Irwin McGraw-Hill, New York.

[19] Bhuyan, S. (2007) The "People” Factor in Cooperatives: An Analysis of Member's Attitudes and Behavior. Canadian Journal of Agricultural Economics, 55, 275-298. http://dx.doi.org/10.1111/j.1744-7976.2007.00092.x

[20] Torrington, D. and Hall, L. (1995) Personnel Management: HRM in Action. 3rd Edition, Prentice Hall, London.

[21] Commission of the European Communities (2003) Green Paper: Entrepreneurship in Europe. COM 27 Final, Brussels. http://ec.europa.eu/invest-in-research/pdf/download_en/entrepreneurship_europe.pdf

[22] European Commission (2002) Final Report of the Expert Group Education for Entrepreneurship: Making Progress in Promoting Entrepreneurial Attitudes and Skills through Primary and Secondary Education. Enterprise Directorate General.

http://ec.europa.eu/enterprise/policies/sme/files/support_measures/training_education/doc/entrepreneurship_education_ final_en.pdf

[23] Hayton, J.C., George, G. and Zahra, S.A. (2002) National Culture and Entrepreneurship: A Review of Behavioral Research. Entrepreneurship Theory and Practice, 26, 33-52.

[24] Rae, D. (2000) Understanding Entrepreneurial Learning: A Question of How? International Journal of Entrepreneurial Behaviour and Research, 6, 145-159. http://dx.doi.org/10.1108/13552550010346497

[25] Gopinath, C. and Sawyer, J. (1999) Exploring the Learning from an Enterprise Simulation. Journal of Management Development, 18, 477-489. http://dx.doi.org/10.1108/02621719910273596

[26] Leitch, C.M. and Harrison, R.T. (1999) A Process Model for Entrepreneurship Education and Development. International Journal of Entrepreneurial Behavior and Research, 5, 83-109. http://dx.doi.org/10.1108/13552559910284065

[27] Hansemark, O.C. (1998) The Effects of an Entrepreneurship Program on Need for Achievement and Locus of Control 
of Reinforcement. International Journal of Entrepreneurial Behavior and Research, 4, 28-50. http://dx.doi.org/10.1108/13552559810203957

[28] Herbig, P. and Miller, J.C. (1992) Culture and Technology: Does the Traffic Move in Both Directions? Journal of Global Marketing, 6, 75-104. http://dx.doi.org/10.1300/J042v06n03_05

[29] Region of Crete (2012) Economic Facts. http://www.crete.gov.gr/index.php?option=com_content\&view=article\&id=4138\&Itemid=288\&lang=en

[30] (1975) On Mountain and Hill Farming and Farming in Certain Less-Favored Areas. Official Journal of European Commission, Council Directive No. 268, L128, 1-7.

[31] Commission of the European Communities (2004) Communication from the Commission to the Council and the European Parliament, the European Economic and Social Committee and the Committee of Regions: On the Promotion of Co-Operative Societies in Europe. COM 18, Brussels. http://eur-lex.europa.eu/legal-content/EN/TXT/?uri=CELEX:52004DC0018

[32] Commission of the European Communities (2000) Communication from the Commission to the Council, the European Parliament, the Economic and Social Committee and the Committee of the Regions, Acting Locally for Employment: A Local Dimension for the European Employment Strategy. COM 196 Final, Brussels. http://eur-lex.europa.eu/LexUriServ/LexUriServ.do?uri=COM:2000:0196:FIN:EN:PDF

[33] Mason, J. (2002) Qualitative Researching. 3rd Edition, Sage Publications, Thousand Oaks, London.

[34] Patton, M.Q. (2002) How to Use Qualitative Methods and Evaluation Methods. Sage Publications, Newbury Park.

[35] Yin, R.K. (2009) Case Study Research: Design and Methods. 4th Edition, Sage Publications, Thousand Oaks.

[36] Bryman, A. (2008) Social Research Methods. Oxford University Press, Oxford.

[37] Riege, A.M. (2003) Validity and Reliability Tests in Case Study Research: A Literature Review with "Hands-On” Applications for Each Research Phase. Qualitative Market Research: An International Journal, 6, 75-86. http://dx.doi.org/10.1108/13522750310470055

[38] Eisenhardt, K.M. (1989) Building Theories from Case Study Research. Academy of Management Review, 14, 532-550.

[39] Lincoln, Y.S. and Guba, E.G. (1985) Naturalistic Inquiry. Sage Publications, London.

[40] Rubin, H.J. and Rubin, I.S. (1995) Qualitative Interviewing: The Art of Hearing Data. 2nd Edition, Sage Publications, London.

[41] Judd, C., Smith, E. and Kidder, L. (1991) Research Methods in Social Relations. 6th Edition, Holt, Rinehart and Winston, New York.

[42] Weber, R.P. (1990) Basic Content Analysis. Sage Publications, London.

[43] Krippendorff, K. (2004) Content Analysis: An Introduction to Its Methodology. Sage Publications, London.

[44] Holsti, O. (1969) Content Analysis for the Social Studies and Humanities. Addison-Wesley Publications, Philippines.

[45] Strauss, A. and Corbin, J. (1994) Grounded Theory Methodology: An Overview. In: Denzin, N.K. and Lincoln, Y.S., Eds., Handbook of Qualitative Research, Sage Publications, London, 1-18.

[46] Conger, J. and Kanungo, R. (1988) Behavioral Dimensions of Charismatic Leadership. In: Conger, J.A., Kanungo, R.N. and Associates, Eds., Charismatic Leadership: The Elusive Factor in Organizational Effectiveness, Jossey Bass, San Fransico, 78-97.

[47] Timmons, J.A., Smollen, L.E. and Dingee A.L.M. (1985) New Venture Creation: A Guide to Entrepreneurship. 2nd Edition, Richard D. Irwin Inc., Homewood. 
Scientific Research Publishing (SCIRP) is one of the largest Open Access journal publishers. It is currently publishing more than 200 open access, online, peer-reviewed journals covering a wide range of academic disciplines. SCIRP serves the worldwide academic communities and contributes to the progress and application of science with its publication.

Other selected journals from SCIRP are listed as below. Submit your manuscript to us via either submit@scirp.org or Online Submission Portal.
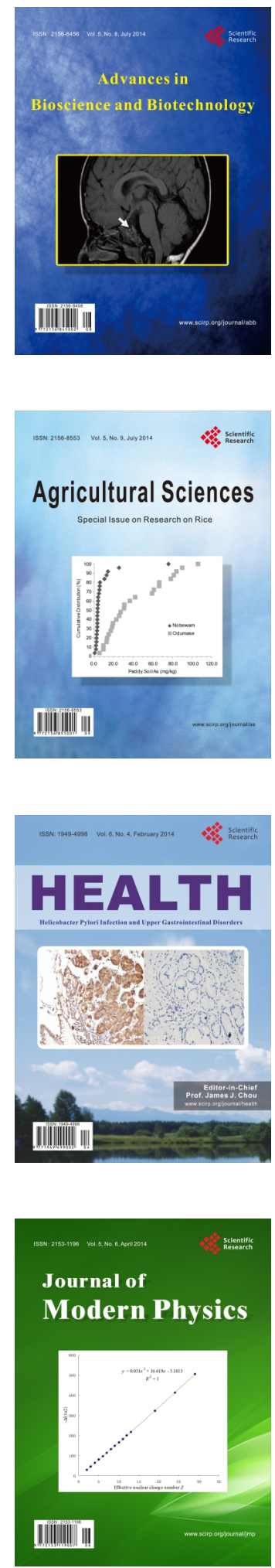
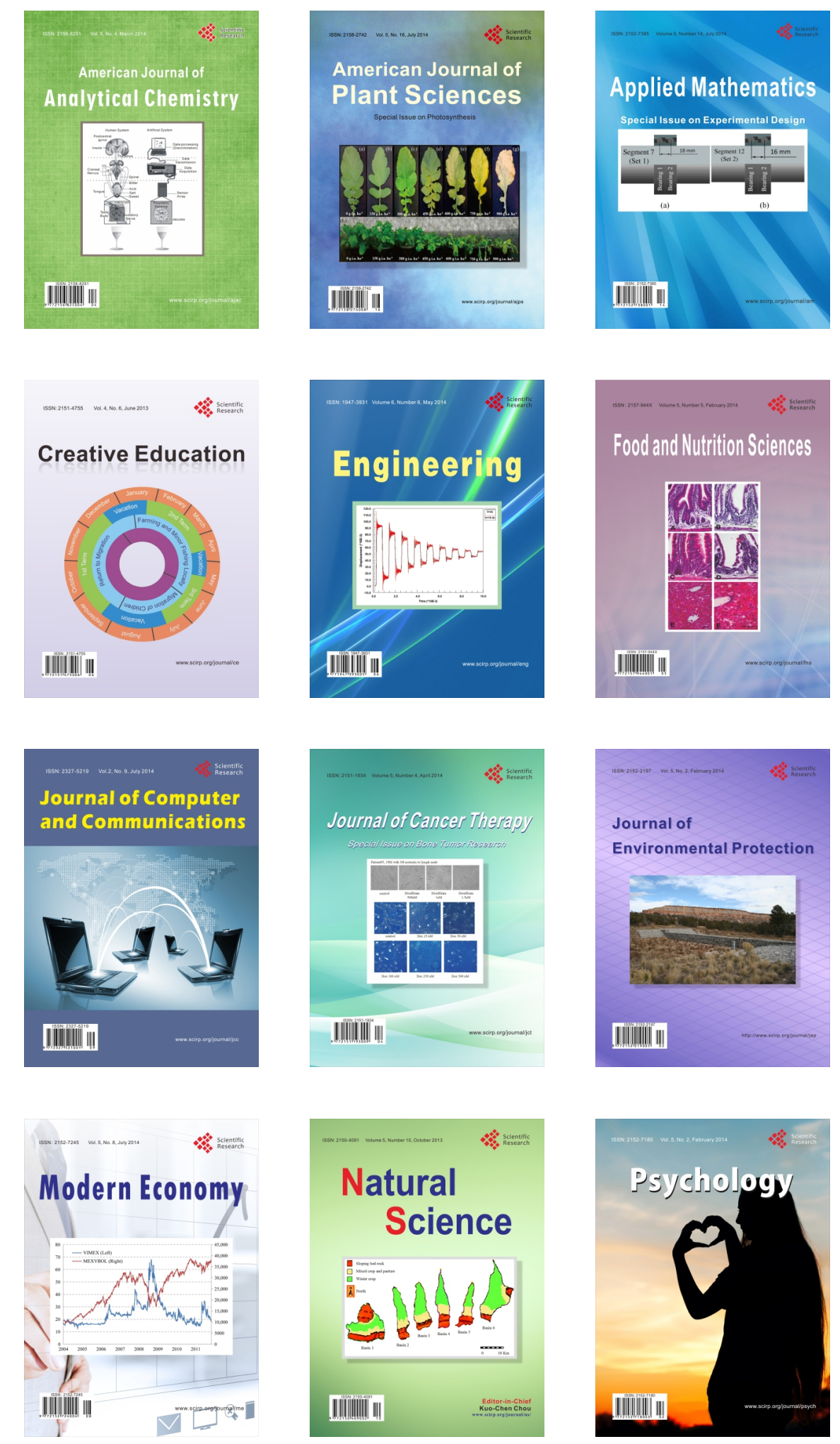